\title{
Multi-Technique Characterization of Pictorial Organic Binders on XV Century Polychrome Sculptures by Combining Micro- and Non-Invasive Sampling Approaches
}

\author{
Elena C. L. Rigante ${ }^{1}$, Cosima D. Calvano ${ }^{1,2,3, * \mathbb{D}}$, Rosaria A. Picca ${ }^{1,2,3} \mathbb{D}^{\mathbb{D}}$, Simona Armenise ${ }^{4}$, \\ Tommaso R. I. Cataldi ${ }^{1,2}$ and Luigia Sabbatini ${ }^{1,2,3, *(\mathbb{D})}$ \\ 1 Dipartimento di Chimica, Università degli Studi di Bari Aldo Moro, 70126 Bari, Italy; \\ elena.rigante@uniba.it (E.C.L.R.); rosaria.picca@uniba.it (R.A.P.); tommaso.cataldi@uniba.it (T.R.I.C.) \\ 2 Centro Interdipartimentale SMART, Università degli Studi di Bari Aldo Moro, 70126 Bari, Italy \\ 3 Centro Interdipartimentale "Laboratorio di Ricerca per la Diagnostica dei Beni Culturali", Università degli \\ Studi di Bari Aldo Moro, 70126 Bari, Italy \\ 4 Restoration, Conservation and Diagnostics of Cultural Heritage via Vitantonio di Cagno 1, 70124 Bari, Italy; \\ simoresta@gmail.com \\ * Correspondence: cosimadamiana.calvano@uniba.it (C.D.C.); luigia.sabbatini@uniba.it (L.S.)
}

\section{check for}

updates

Citation: Rigante, E.C.L.; Calvano, C.D.; Picca, R.A.; Armenise, S.; Cataldi, T.R.I.; Sabbatini, L.

Multi-Technique Characterization of Pictorial Organic Binders on XV Century Polychrome Sculptures by Combining Micro- and Non-Invasive Sampling Approaches. Appl. Sci. 2021, 11, 8017. https://doi.org/ 10.3390/app11178017

Academic Editor: Antonella Casoli

Received: 28 July 2021

Accepted: 27 August 2021

Published: 30 August 2021

Publisher's Note: MDPI stays neutral with regard to jurisdictional claims in published maps and institutional affiliations.

Copyright: (c) 2021 by the authors. Licensee MDPI, Basel, Switzerland. This article is an open access article distributed under the terms and conditions of the Creative Commons Attribution (CC BY) license (https:/ / creativecommons.org/licenses/by/ $4.0 /)$.

\begin{abstract}
A stony sculptural composition of the Nativity Scene is preserved in Altamura's Cathedral (Apulia, Italy). This commonly called Apulian "presepe", attributed to an unknown stonemason, is composed of polychrome carbonate white stone sculptures. While earlier stratigraphic tests have unveiled a complex superimposition of painting layers-meaning that several editions of the sculptures succeeded from the 16th to 20th century-a chemical investigation intended to identify the organic binding media used in painting layers was undertaken. Drawing on current literature, two strategies were exploited: a non-invasive in situ digestion analysis and an approach based on microremoval of painting film followed by the Bligh and Dyer extraction protocol. Both peptide and lipid mixtures were analyzed by matrix-assisted laser desorption/ionization-mass spectrometry (MALDIMS) and reversed-phase liquid chromatography coupled to mass spectrometry by electrospray ionization (RPLC-ESI-MS). Attenuated total reflectance Fourier-transform infrared spectroscopy (ATR-FTIR) examinations were also performed on micro-samples of painting films before lipids and proteins extraction. While human keratins were found to be common contaminants of the artwork's surfaces, traces of animal collagen, siccative oils, and egg white proteins were evidenced in different sampling zones of the sculptures, thus suggesting the use of non-homogeneous painting techniques in the colored layers.
\end{abstract}

Keywords: organic binders; MALDI; pigments; ATR-FTIR; statue; trypsin digestion

\section{Introduction}

Since ancient times, milk, egg, animal glue, siccative oils (i.e., linseed oil, poppy seed oil), and plant gums from Acacia, Tragacanth, and Arabic were employed by artists in painting formulations [1-3]. These components act as binders, also called media, and perform some important tasks thanks to their chemical and physical properties including pigment dispersion, cohesion and adhesion on the support, pigments protection from atmospheric agents, and transparency, thus keeping the pigment's optical properties intact [1-6]. Chemical examination and characterization of organic binders in polychrome statues are the key to understand the materials employed by the artist and awareness of his/her style and employed technique. The study draws from the literature on binders from wooden, stone, and clay sculptures are challenging for several reasons. Firstly, the existence of complex stratigraphy due to the subsequent applications of painting layers from the original to the latest version of the sculpture makes cross-section analysis and invasive sample removal needed for the assessment of the binder's typology [7-11]. Secondly, 
ancient sculptures may likely have been damaged and repeatedly restored over time, thus implying the occurrence of broken pieces replacement with less ancient ones [12]. Thirdlyif not retouched-ancient statues maintain only traces of polychromy [13]. Moreover, the presence of human keratin-type proteins and peptides may interfere with the chemical investigations $[7,8]$. Finally, medium concentration in the sample is usually low because of a reduced binder-to-pigment ratio in the pictorial mixture [5]. Nevertheless, in the last two decades, to establish the chemical composition of the paint layers, diagnostic works have been performed on polychrome sculptures referable to different ages and countries. For example, high-performance liquid chromatography-mass spectrometry (HPLC-MS) and matrix-assisted laser desorption ionization (MALDI)-MS techniques have been used for the detection of both animal glue and egg peptides in a 16th century Moravian sculpture [7,8], gas chromatography (GC)-MS has been employed to distinguish caseins, egg proteins, and siccative oils as binding media from Medieval polychrome sculptures [14], as well as pyrolysis-GC/MS has revealed the presence of marker products of animal glue in samples from clay sculptures of Hua Yan Temple of the Liao Dynasty [15]. Furthermore, caseins, egg white, animal glue, and plant gums were discovered in many samples of Chinese polychrome grotto relics by means of the enzyme-linked immunosorbent assay (ELISA) [16].

Altamura's Cathedral (Apulia, Italy) hosts a monumental representation of the Nativity Scene-called presepe - which was commissioned and financed in 1587 by Iacobutius De Cubutiis as proven by an adjacent commemorative plaque. This picturesque composition counts 47 sculptural elements made of polychrome carbonate white stones except for the statue of infant Jesus that was stolen and replaced with a modern gypsum element. The artwork shows typical features of Renaissance Apulian presepe, namely, a solemn and monumental structure, polychromatic elements, and a narrative scheme that is organized in horizontally superimposed scenes [17-19]. Diagnostic activity on the mobile sculptures began in 2019 and involved stratigraphic tests as well as optical microscopy investigation of pictorial film's cross-sections. These studies revealed the existence of several overlapped layers of painting, suggesting numerous renovations and restorations occurred between the end of the 16th and 20th centuries. Here, two polychrome sculptural figures, the musician angel playing viola and a lying lamb (Figure 1), were investigated to identify and distinguish the organic binders used in color layers belonging to different periods. Samples for spectrometric and spectroscopic analyses were acquired by recurring to both a non-invasive and a micro-invasive approach. In the first case, a recently developed method was adopted $[20,21]$ using a small piece of poly(2-hydroxyethyl methacrylate)/poly (vinylpyrrolidone) hydrophilic gel $(3 \mathrm{~mm} \times 3 \mathrm{~mm})$ loaded with a dual-enzyme solution (trypsin/chymotrypsin, 1:1, v:v) and then applied on the statue surface to operate an in situ digestion of the pictorial proteinaceous fraction. The peptide mixture absorbed by the gel's porous structure was then released into a suitable extraction solution. This novel strategy based on in situ multi-enzyme digestion of proteinaceous material of paint layer binders allowed a more confident binder identification ensuing a bottom-up proteomic approach. By this protocol it was likely to exploit a non-invasive or minimally invasive sampling of proteins taking advantage of the occurrence of trypsin and chymotrypsin which synergistically work to increase protein coverage.

Some extra samples were also collected by gently scraping minute quantities (milligrams) of the painting layer; they were first analyzed by attenuated total reflectance Fourier-transform infrared spectroscopy (ATR-FTIR) to investigate both organic and inorganic fraction (i.e., the pigments and fillers employed). Being ATR-FTIR a non-destructive technique, samples were later extracted by the Bligh and Dyer (BD) protocol $[22,23]$ to separate proteinaceous and lipid components. Peptide mixtures were analyzed by MALDIMS and reversed-phase LC coupled with electrospray ionization (ESI) and tandem MS confirming the presence of animal glue and egg as binders. The BD chloroform/methanol solution-containing phospholipids and triglycerides—was examined by MALDI-MS and tandem MALDI-MS/MS. ATR-FTIR characterization was particularly useful to identify 
some specific pigments as well as additional compounds present in the investigated layers. Moreover, it was used as a screening tool to diagnose the presence of possible binders before carrying out the complete MS analysis. The combination of ATR-FTIR and MS data was very successful to distinguish and recognize the sample composition of painting layers, revealing an uneven stratigraphy in different sampling zones of the sculptures, exhibiting animal glue, siccative oils, and egg white proteins as binders.

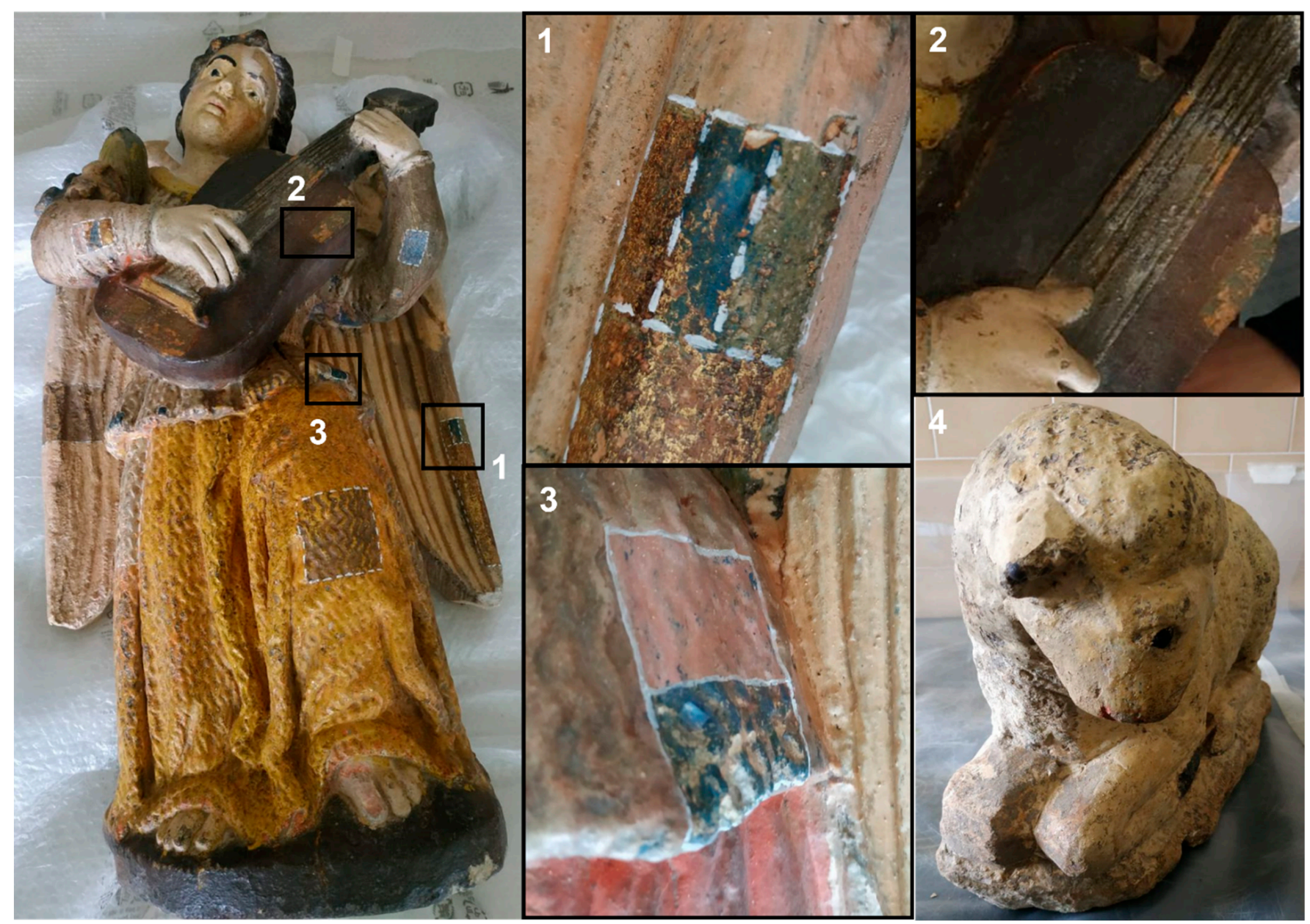

Figure 1. Sculptures representing the musician angel with viola (left) and the lying lamb (right end). Details of the sampled zones and their stratigraphy are in sections 1 (wing), 2 (viola), 3 (blouse), and point 4 (lying lamb).

\section{Materials and Methods}

\subsection{Chemicals}

Water, acetonitrile (ACN), formic acid (FA), chloroform, methanol, ammonium bicarbonate, $\alpha$-cyano-4-chloro-cinnamic acid (CClCA), dithiothreitol (DTT), iodoacetamide, trypsin (proteomics grade from porcine pancreas), and chymotrypsin (sequencing grade from bovine pancreas) were obtained from SigmaAldrich (Milan, Italy). RapiGest SF Surfactant was purchased from Waters. Nanorestore Gel ${ }^{\circledR}$ Medium Water Retention-("Extra Dry", Italian Patent from Consorzio CSGI, University of Florence), employed for in situ digestions, is a poly(2-hydroxyethyl methacrylate)/poly(vinylpyrrolidone) (pHEMA/PVP) hydrogel [24-27].

\subsection{Dual-Enzyme In Situ Protocol}

Small pieces ( $3 \mathrm{~mm} \times 3 \mathrm{~mm}$ ) of water-swollen pHEMA/PVP hydrogel [27] were dried in air ambient until they lost $20 \%$ of their weight. Each piece of gel was then immersed in a 
water solution composed of $20 \mu \mathrm{L}$ of trypsin and $20 \mu \mathrm{L}$ of chymotrypsin (both $20 \mu \mathrm{g} / \mathrm{mL}$ ) for $30 \mathrm{~min}$ allowing the enzymes to penetrate into the hydrogel. In situ digestion of proteinaceous binders was accomplished by applying the enzyme-loaded hydrogel pieces onto the painting surface for $30 \mathrm{~min}$. After removal, each gel was moved into $100 \mu \mathrm{L}$ of a $70 \%: 30 \%$ ACN: $\mathrm{H}_{2} \mathrm{O}$ with $0.1 \%$ FA solution and there left for 20 min in an ultrasonic bath at $30{ }^{\circ} \mathrm{C}$ to promote a quantitative release of peptides. The peptides solution was vacuum-dried to preconcentrate the sample, reconstituted in $20 \mu \mathrm{L}$ of 70:30\% ACN: $\mathrm{H}_{2} \mathrm{O}$ plus $0.1 \%$ FA and then analysed by MALDI-MS(/MS) and RPLC-ESI-MS(/MS).

\subsection{Bligh and Dyer Extraction Protocol}

The samples scraped from the musician angel and from the lying lamb sculptures (2-5 mg) were ground down using a pestle and a mortar. A total of $150 \mu \mathrm{L}$ of $\mathrm{CHCl}_{3} / \mathrm{MeOH}$ 1:2 (v:v) were added to the sample and the solution was ultrasonicated for $20 \mathrm{~min}$. Then, $50 \mu \mathrm{L}$ of $\mathrm{CHCl}_{3}$ followed by $50 \mu \mathrm{L}$ of $\mathrm{H}_{2} \mathrm{O}$ were added. The mixture was ultrasonicated for $20 \mathrm{~min}$ after each addition. The final solution was centrifuged $(10 \mathrm{~min}$ at $3000 \times \mathrm{g})$ to allow phase separation. The lower organic phase was collected, dried under a nitrogen stream, reconstituted into $100 \mu \mathrm{L}$ of $\mathrm{CHCl}_{3} / \mathrm{MeOH}$ 1:1 (v:v), and prepared for lipid MALDI analysis.

\subsection{Enzymatic Digestion}

A typical tryptic digestion protocol was applied. The upper aqueous phase obtained from BD extraction was pre-concentrated to $20 \mu \mathrm{L}$, added with $50 \mu \mathrm{L}$ of RapiGest reagent (Waters) $\left(1 \mathrm{mg} / \mathrm{mL}\right.$ in $\left.\mathrm{NH}_{4} \mathrm{HCO}_{3} 50 \mathrm{mM}\right)$ and kept at $60{ }^{\circ} \mathrm{C}$ for $1 \mathrm{~h}$. Then, $5 \mu \mathrm{L}$ of $50 \mathrm{mM}$ DTT were added and the mixture was incubated for $20 \mathrm{~min}$ at $60^{\circ} \mathrm{C} .5 \mu \mathrm{L}$ of $150 \mathrm{mM}$ iodoacetamide were added and the solution was maintained in the dark at room temperature for $15 \mathrm{~min}$. Finally, $25 \mu \mathrm{L}$ of sequencing grade trypsin solution $(20 \mu \mathrm{g} / \mathrm{mL})$ were added and the mixture was incubated at $37^{\circ} \mathrm{C}$ overnight. Enzymatic digestion was stopped by adding $3 \mu \mathrm{L}$ of formic acid $98 \%$. When needed, sample purification was carried out using ZipTip with $6 \mu \mathrm{L}$ C18 resin (Millipore); the resin was at first conditioned with $10 \mu \mathrm{L}$ of ACN followed by $10 \mu \mathrm{L}$ of FA $0.1 \%$ for acidification, later it was loaded with sample and washed with $10 \mu \mathrm{L}$ of FA $0.1 \%$. Finally, the elution step was made with $10 \mu \mathrm{L}$ of $\mathrm{ACN}: \mathrm{H}_{2} \mathrm{O}$ 70:30 added with 0.1\% FA (v:v).

\subsection{MALDI-MS(/MS)}

All experiments were performed using a 5800 MALDI-ToF/ToF analyzer (AB SCIEX, Darmstadt, Germany) equipped with a neodymium-doped yttrium lithium fluoride (Nd:YLF) laser $(345 \mathrm{~nm})$, in a reflectron positive mode, with $10 \mathrm{ppm}$ mass accuracy. A total of $3 \mu \mathrm{L}$ of the analyte solutions were mixed 1:1 (v:v) with matrix CClCA $(10 \mathrm{mg} / \mathrm{mL}$ in 70:30 ACN: $\mathrm{H}_{2} \mathrm{O}$ and $0.1 \%$ FA). Moreover, $1 \mu \mathrm{L}$ of the mixture was deposited on the target plate, dried at room temperature, and washed on spot with $1 \mu \mathrm{L} \mathrm{H}_{2} \mathrm{O}$ LC-MS grade. External peptide standards purchased from Sciex were used for mass calibration in the range $700-5000 \mathrm{~m} / \mathrm{z}$. In MS and MS/MS modes, 1000 laser shots were accumulated by a random raster scan, at laser pulse rates of 400 and $1000 \mathrm{~Hz}$, respectively; each mass spectrum was averaged on at least five single spectra (1000 laser shots each). The delayed extraction time was set at $240 \mathrm{~ns}$.

\subsection{RPLC-ESI-MS(/MS)}

Reversed-phase liquid chromatographic runs were performed using a VelosPro (Thermo Scientific, Waltham, MA, USA) instrumentation, i.e., a double linear trap mass spectrometer coupled with Ultimate 3000 HPLC system (Dionex, Thermo Scientific) and HESI (heated electrospray ionization) interface. The chromatographic section was composed of a C18 column AerisTM $3.6 \mu \mathrm{m}$ widepore XB-C18 $250 \times 2.1 \mathrm{~mm}$ (Phenomenex, Torrance, CA, USA) working at $0.2 \mathrm{~mL} / \mathrm{min}$ flow and $40{ }^{\circ} \mathrm{C}$. The mobile phase composition was $\mathrm{H}_{2} \mathrm{O}(\mathrm{A})$ and ACN (B) both containing formic acid $0.1 \%$ in volume. The mobile phase elution was set 
as follows: $\min 05 \% \mathrm{~B}, \min 2$ isocratic $5 \% \mathrm{~B}, \min 20$ up to $60 \% \mathrm{~B}, \min 22$ up to $100 \% \mathrm{~B}$, min 26 isocratic $100 \% \mathrm{~B}$, min 30 up to $5 \% \mathrm{~B}$, min 35 isocratic $5 \% \mathrm{~B}$. Mass spectrometer parameters were sheath gas flow rate 35 arbitrary units (a.u.); spray voltage $3.5 \mathrm{kV}$; capillary temperature $320^{\circ} \mathrm{C}$; source heater temperature $45^{\circ} \mathrm{C}$; S-Lens RF Level 60 a.u. MS data were acquired in Data Dependent mode in the range 500-2000 m/z. Precursor ions tandem MS fragmentations were performed in CID (collision induced dissociation) fragmentation mode with $35 \%$ a.u. energy.

\subsection{ATR-FTIR}

Spectroscopic characterization was performed on a Spectrum Two Perkin Elmer instrument mounting the universal ATR accessory equipped with a diamond prism. Spectra were acquired in transmission mode in the wavenumber range $4000-400 \mathrm{~cm}^{-1}$ with a resolution of $2 \mathrm{~cm}^{-1}$ collecting 64 scans. Background was acquired against air. Signal's attribution was carried out by comparison with literature data and with spectra acquired on standard samples applying the same instrumental parameters.

\subsection{Data Processing}

Raw MALDI-MS(/MS) and RPLC-ESI-MS(/MS) files were processed using the software Data Explorer 4.11 and Xcalibur 4.1, respectively. mMass 5.5.1 was used for the peak list extraction from txt files. Bioinformatic research for peptides was carried out with Protein Prospector MS Fit and MS Tag in SwissProt database among all taxonomies, tolerance set on 0.2 Da for parent ion and 0.3 Da for ion fragments in the case of MS/MS datasets, up to four acceptable missed cleavages and the following variable peptide modifications: oxidation of methionine, proline and tryptophan, deamidation of asparagine and glutamine and phosphorylation of serine, threonine and tyrosine. Carbamidomethylation of cysteine was set as a constant modification only for conventionally digested samples. Bioinformatic research for lipids was made with the software Online Lipid Calculator and LIPID MAPS ${ }^{\circledR}$ Lipidomics Gateway setting a 0.2 Da tolerance. ATR-FTIR spectra were processed with the software used for acquisition; resulting data were exported in txt format to plot the spectrum in OriginPro 2016.

\section{Results and Discussion}

The sampling for this study was accomplished on small zones of the sculptures representing the musician angel with a viola and a lying lamb. Since the angel assumed a prominent role in the Nativity scene, multiple retouching has been carried out, thus a highly overlapped painting is present. Stratigraphic trials performed on the wing, the gown, the blouse, and the viola allowed us to identify the plural editions of the sculpture.

\subsection{Angel's Wing, Blue Layer (Sampled Point 1)}

The analyzed point on the blue layer of musician angel's left wing revealed a complex stratigraphy under the most recent pale layer unveiling three different colored layers: the most ancient one is gilded bole, the second is blue, and the third appears green (Figure 1, Sampled point 1). On the blue layer area, we performed an extensive investigation by applying both the micro- and the non-invasive approaches. The extracted peptides by the non-invasive strategy were examined by MALDI-MS (Figure 2A) and the $m / z$ values were inserted in the database for peptide mass fingerprinting (PMF) search. The spectra were also manually compared to those of the replicas prepared as previously described $[20,21]$ and some chosen peptides were subjected to MS/MS analysis as a confirmation. For a direct comparison, Figure 2B shows the MALDI mass spectrum of the painting replica composed of egg white mixed with calcium carbonate, on which the same protocol (gel loaded with double enzyme) was carried out. As mentioned above, some critical matters to be managed in ancient statue samples are represented by the likely color stratigraphy, the interventions, retouching, and piece substitution with a continuous human manipulation that drastically reduced proteome identification alongside the well-known aging processes 
often enhanced by entrapped pigments. The MALDI mass spectrum of dual-enzyme digest (Figure 2A) is dominated by intense peaks related to human keratins (see peak signals at $m / z 1064.6,1234.6,1262.5,1302.6,1357.6,1707.7,1838.8$ ) that contaminated the artwork's surface. The identity of keratin-type peptides was achieved through RPLC coupled to tandem MS experiments. As an example, the tandem MS spectrum of the doubly charged ion at $\mathrm{m} / \mathrm{z} 854.7$ eluting at $12.97 \mathrm{~min}$ (Figure S1, Supplementary Material) strongly agrees with the sequence GSIGGGFSSGGFSGGSFSR of keratin type I cytoskeletal 10, Homo sapiens, corresponding to the monocharged ion at $m / z 1707.7$ detected in the MALDI-MS spectrum (see Figure 2A). Notably, several intense peaks of peptides were generated by trypsin/chymotrypsin auto- and mutual digestion such as $\mathrm{m} / \mathrm{z} 1016.5,1045.5,1092.4,1493.6$, and 1541.5 (see Figure 2A), thus suggesting the very low abundance of proteinaceous material in this examined sample and investigated zone. These assignments were supported by Protein Prospector-MS Digest and again verified by RPLC-ESI-CID tandem MS experiments. For example, the ion at $m / z 1541.6(\mathrm{~m} / \mathrm{z} 771.6$ as doubly charged ion) corresponds to the peptide IVN(deamidated)GEEAVPGSWPW belonging to the protein chymotrypsinogen A, Bos taurus (Figure S2). Besides interfering signals, both spectra of Figure 2 share several other minor peaks that successfully match with ovalbumin (i.e., $\mathrm{m} / \mathrm{z}$ $1345.7,1581.6,1687.8,1773.9,1858.9$, and 1859.9), ovomucoid $(\mathrm{m} / \mathrm{z}$ 1106.5), ovotransferrin ( $\mathrm{m} / \mathrm{z}$ 1179.6), and vitellogenin I and II at $\mathrm{m} / \mathrm{z} 1079.5$ and 1179.6, respectively. The search by Protein Prospector-MS Fit corroborated the above results of G. gallus taxonomy. Egg white chymotryptic peptides in the blue layer sample were further confirmed by data-dependent RPLC-ESI-MS/MS analysis. The occurrence of a peak signal at $\mathrm{m} / z 930.6^{2+}$, eluted at $14.94 \mathrm{~min}$ and corresponding to $\mathrm{m} / \mathrm{z} 1859.8$ in the MALDI-MS spectrum, was recognized as the peptide ELIN(deamidated)SWVESQTNGIIR derived from ovalbumin of G. gallus (Figure S3). Deamidation is a chemical reaction in which an amide functional group in the side chain of the amino acids asparagine or glutamine is converted to carboxylic derivative, thus producing a +0.984 Da mass shift. According to literature, deamidation is the main non-enzymatic modification occurring during protein aging along with oxidation, both commonly observed in proteins from ancient artworks [28]. From the very low abundance of the sampled proteins, one could infer that egg white was used as a protective coating rather than as the unique binder, thus the micro-invasive sampling on this point was carried out. ATR-FTIR characterization allowed the identification of the blue pigment giving additional information about the organic component present in this investigated layer (Figure 3). The sharp signal falling at $2087 \mathrm{~cm}^{-1}$ is uniquely assigned to the stretching vibration of the $\mathrm{CN}$ group of Prussian Blue [29], which was first introduced at the beginning of the XVIII century. Moreover, signals ascribable to other inorganic components such as basic lead carbonate (at $3508,1398,680 \mathrm{~cm}^{-1}$ ) and calcite (vibrations at $873,712 \mathrm{~cm}^{-1}$ ) as well as to sulfate groups $\left(1076 \mathrm{~cm}^{-1}\right)$ could be identified [30]. The presence of siccative oil as a binder was corroborated by the intense peaks at 1728, 2920, and $2850 \mathrm{~cm}^{-1}$ : while the first one was assigned to ester $\mathrm{C}=\mathrm{O}$ stretching in the triacylglycerols of the drying oil, the other two to asymmetric and symmetric methylene stretching of the alkyl chains. The spectral features at 1237 and $1150 \mathrm{~cm}^{-1}$ are compatible with the C-O-C stretching, also typical of the triglyceride ester linkages found in oils [31]. Oxidation of lipids is suggested by the wide band around $3440 \mathrm{~cm}^{-1}$, assigned to $-\mathrm{OH}$ stretching [32]. Furthermore, the presence of proteinaceous components is supported by small peaks at 1650 and $1542 \mathrm{~cm}^{-1}$, corresponding to amides I and II vibrational modes [32]. In the latter case, the contribution of metal soaps (e.g., lead carboxylates) cannot be ruled out [32]. 


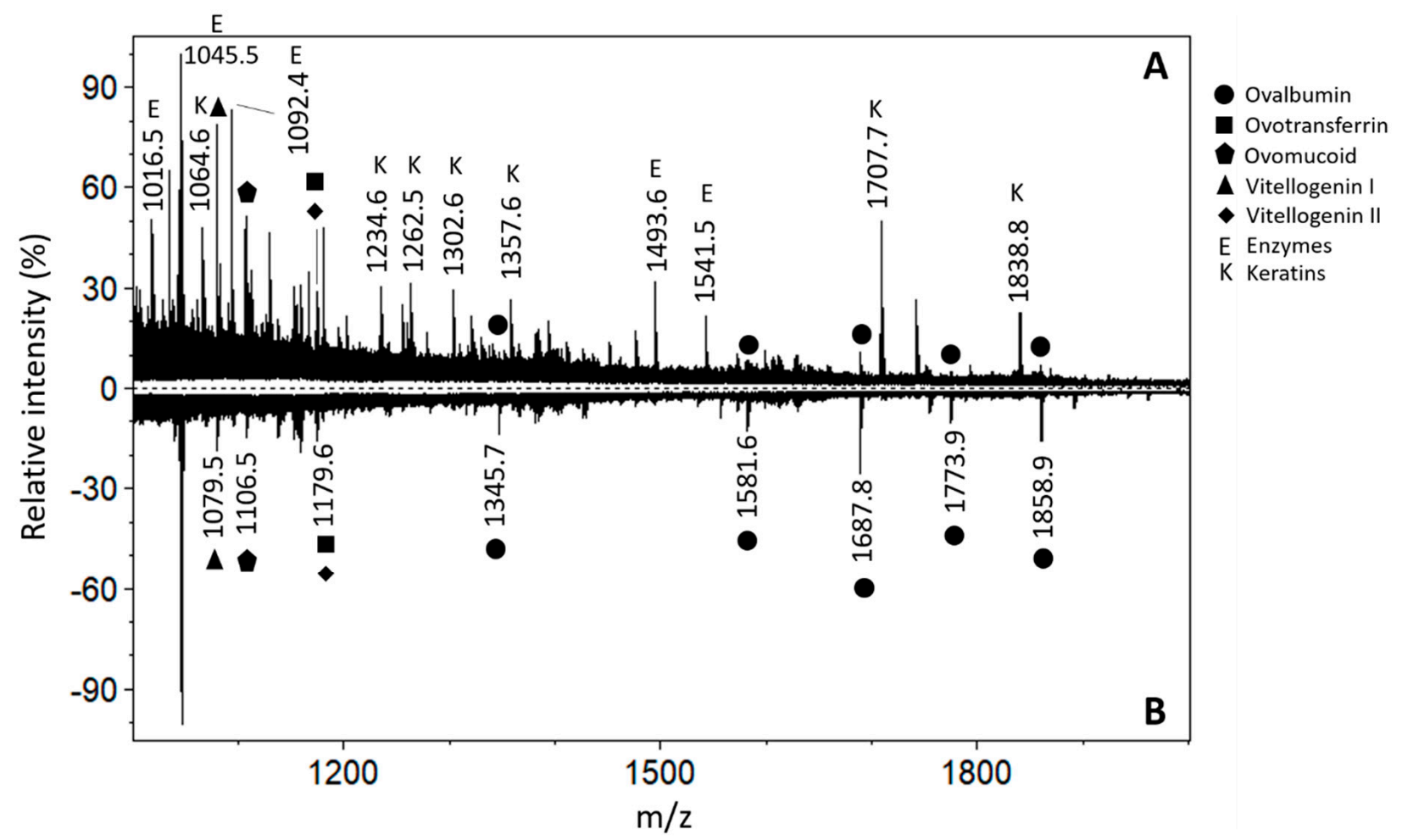

Figure 2. MALDI-MS spectra comparison between protein fraction from angel blue wing (A, above) and paint replica made of egg white mixed to $\mathrm{CaCO}_{3}$ (B, below). K stands for Keratin and $\mathrm{E}$ for Enzyme due to auto-proteolytic digestion.

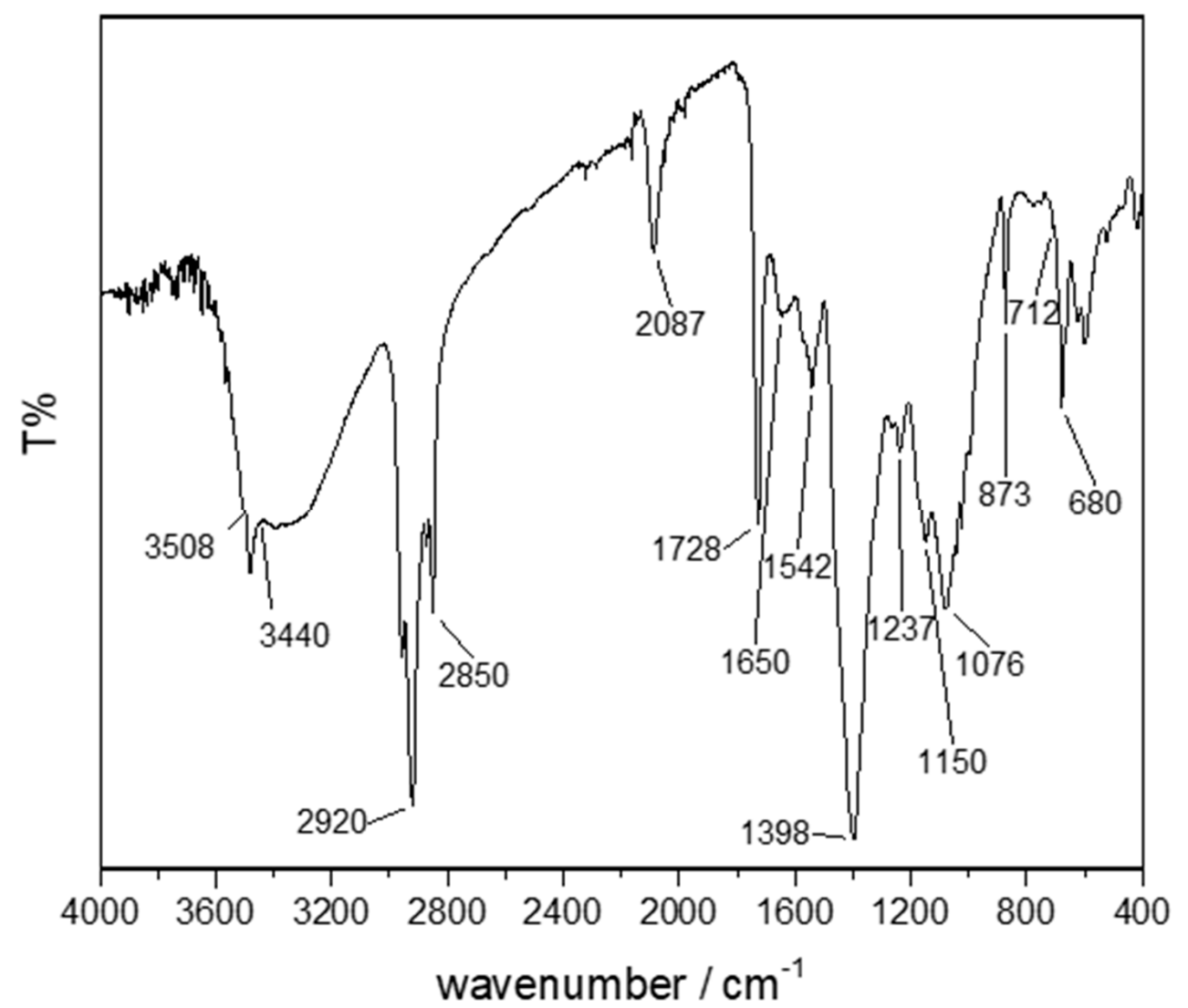

Figure 3. ATR-FTIR spectrum of blue layer (Angel's wing). The main peaks cited in the discussion are labelled. 
After IR analysis, the sample was extracted by the Bligh and Dyer protocol (see Experimental Section), and the lipid fraction was analyzed by MALDI-MS. The spectrum examination of Figure 4A suggests the existence of a siccative oil since some of the most common signals of diacylglycerols (DAGs) at $\mathrm{m} / \mathrm{z} 603.5$ and 617.5 and triacylglycerols (TAGs) at $m / z$ 851.6, 881.6, 895.7, and 953.7 [33,34] were observed as sodiated adducts. It is known that the pigments combined with a binding medium speed up the conversion of lipids into oxidized products being the degree of oxidation directly related to the light exposure and/or aging time. The spectrum of Figure $4 \mathrm{~A}$ is dominated by signals spaced $14 \mathrm{u}\left(\mathrm{CH}_{2}\right.$ units) or $16 \mathrm{u}$ (oxygen unit) apart, mainly due to oxidation reactions or by-products generation containing shorter fatty acyl chains likely formed through the $\beta$-cleavage mechanism [33]. TAGs or DAGs with highly unsaturated fatty acyl chains such as C18:2 and C18:3 were not found due to their faster degradation rate. Indeed, the oxidation rate drastically depends on the number of unsaturations per chain, increasing over ten times for each double bond [35]. Tandem MS analysis of the precursor ion at $\mathrm{m} / \mathrm{z}$ 881.6, reported in Figure 4B, confirmed that the most abundant product ions were those in which the neutral loss of fatty acids is implied. Therefore, peak signals at $\mathrm{m} / z 599.4$ and $m / z 625.4$ correspond to [M-FA(18:1)+Na] $]^{+}$and $[\mathrm{M}-\mathrm{FA}(16: 0)+\mathrm{Na}]^{+}$, thus suggesting the occurrence of C18:1 and C16:0 chains in the examined TAG species. The ion at $m / z 577.4$ was interpreted as [M-FA(18:1)+H] $]^{+}$while the peak signal at $m / z 607.5$ was recognized as [M$\left.\mathrm{FA}(16: 0)-\mathrm{H}_{2} \mathrm{O}+\mathrm{Na}\right]^{+}$. At the low $\mathrm{m} / \mathrm{z}$ range, a small ion at $\mathrm{m} / \mathrm{z} 283.2$ due to protonated fatty acid C18:1 (most likely oleic acid) was detected. The compound was thus recognized as the sodium adduct of TAG(52:2) composed of two oleic fatty acyl chains $(\mathrm{O}, 18: 1)$ and one palmitic fatty acyl chain $(\mathrm{P}, 16: 0)$, usually abbreviated as POO [36,37].

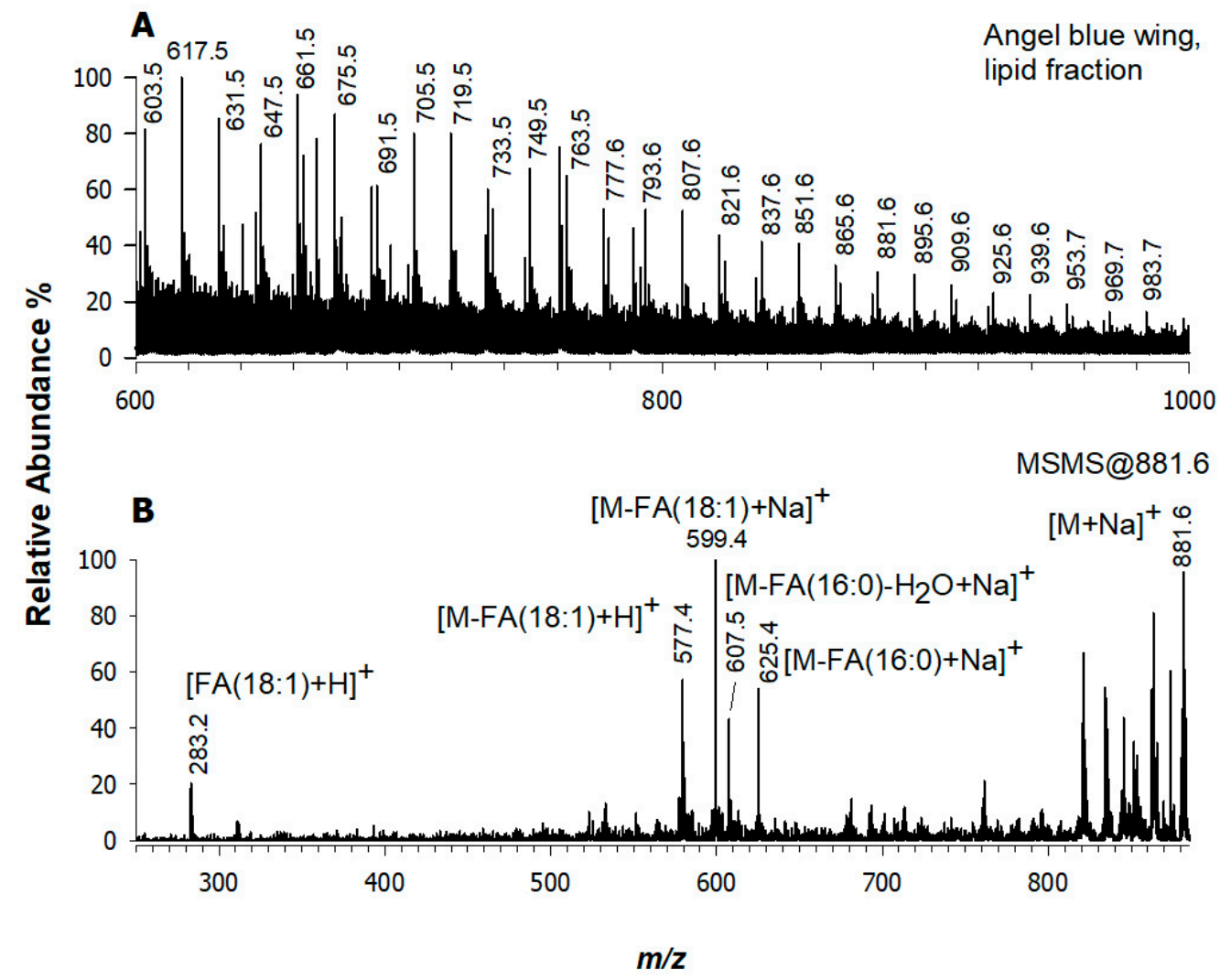

Figure 4. MALDI-MS spectrum of angel's blue wing lipid fraction (A) and MALDI-MS/MS spectrum of the precursor ion as sodium adduct $\left([\mathrm{M}+\mathrm{Na}]^{+}\right)$at $m / z 881.6$ corresponding to [TAG (52:2)+Na] $]^{+}$(B). 


\subsection{Angel's Viola, Brown Layer (Sampled Point 2)}

The non-invasive sampling protocol based on the pHEMA/PVP hydrogel was applied on the most superficial dark brown layer of the angel's musical instrument (Figure 1 Sampled point 2). After a ZipTip purification step, the MALDI-MS spectrum of the peptide mixture was acquired (Figure 5). The resulting PMF was interpreted as follows; most peak signals were typical of collagen peptides, among which, for example, peaks at $m / z 1105.4$, $1267.5,1427.5,1459.5$, and 2130.8 were due to peptides of collagen $\alpha-1$ (I) or collagen $\alpha$-2(I) chains $[20,21,38-40]$. A detailed interpretation of MS signals is reported in Table 1. For the sake of clarity, we refer to "animal collagen" because it is not possible to establish the exact taxonomy of mammal's collagen-type proteins due to the sequences digestion similarity of collagen between bovine, goat, and rabbit [20,41]. Moreover, it should be noted that chymotrypsin/trypsin digestion of mammal collagen sequences produces a PMF which is somewhat overlapping that one generated from the only trypsin digestion. This is consistent with our previous findings [20] and it may be due to a rather low number of chymotryptic cleavage sites i.e., phenylalanine, tyrosine, or tryptophan [42] occurring in collagen. Signals at $\mathrm{m} / \mathrm{z} 1330.5$ and 1540.5-appearing relatively intense in the spectrum and labelled with E-are ascribed to enzymes' auto-proteolytic digestion confirming the low amount of proteinaceous material on the investigated layers.

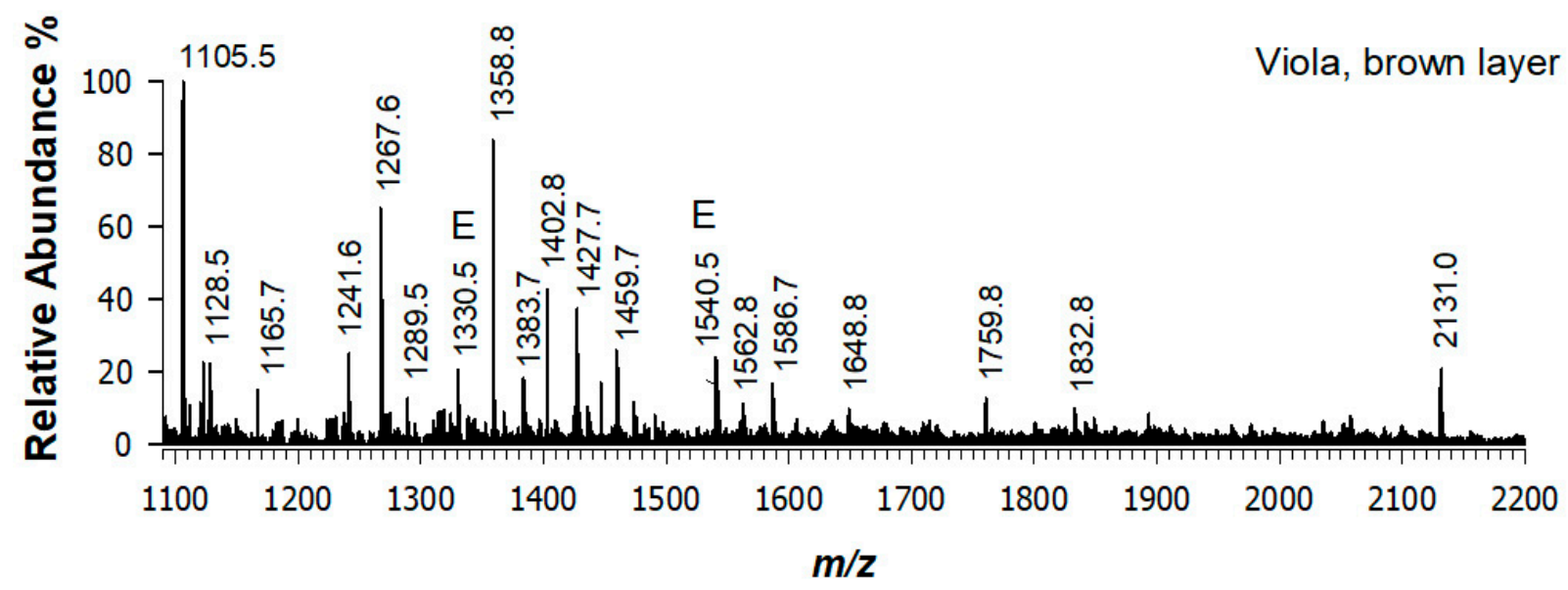

Figure 5. MALDI-MS spectrum of a tryptic/chymotryptic digestion of Angel's viola into a brown layer. The letter E indicates enzyme auto-proteolytic peptides. The complete list of peptides is reported in Table 1.

Table 1. List of the identified peptides in MALDI MS spectrum of dual enzyme digest of angel's viola brown layer with sequences and relevant protein.

\begin{tabular}{|c|c|c|c|}
\hline $\begin{array}{c}\text { Experimental } \\
\mathrm{m} / \mathrm{z}\end{array}$ & $\begin{array}{c}\text { Theoretical } \\
\mathrm{m} / \mathrm{z}\end{array}$ & Sequence & Identified Protein \\
\hline 1105.53 & 1105.57 & (R)GVQGPPGPAGPR(G) + 1 ox & Collagen alpha-1(I) \\
\hline \multirow{2}{*}{1128.50} & 1128.55 & (R)GLPGTPGTDGPK(G) + 2 ox & Collagen alpha-1(II) \\
\hline & 1128.55 & (R)GLAGPPGMPGAR(G) + 3 ox & Collagen alpha-1(III) \\
\hline 1241.59 & 1241.60 & (R)GSPGGPGAAGFPGGR(G) & Collagen alpha-1(III) \\
\hline 1267.62 & 1267.68 & (R)GIPGPVGAAGATGAR(G) + 1 ox & Collagen alpha-2(I) \\
\hline 1289.53 & 1289.59 & (R)GSPGGPGAAGFPGGR(G) +3 ox & Collagen alpha-1(III) \\
\hline \multirow[t]{2}{*}{1358.75} & 1358.67 & (R)ADDANVVRDRDL(E) & Collagen alpha-1(I) \\
\hline & 1427.70 & (R)GSAGPPGATGFPGAAGR(V) & Collagen alpha-1(I) \\
\hline \multirow[t]{2}{*}{1427.73} & 1427.73 & (R)GIPGEFGLPGPAGAR(G) + 2 ox & Collagen alpha-2(I) \\
\hline & 1427.79 & (K)ALLIQGSNDVEIR(A) & Collagen alpha-1(II) \\
\hline \multirow{2}{*}{1435.69} & 1435.68 & (R)GEPGPAGLPGPPGER(G) +3 ox & Collagen alpha-1(I) \\
\hline & 1435.69 & (R)GPPGPPGTNGVPGQR(G) + 3 ox & Collagen alpha-1(III) \\
\hline 1459.70 & 1459.69 & (R)GSAGPPGATGFPGAAGR(V) + 2 ox & Collagen alpha-1(I) \\
\hline 1473.68 & 1473.67 & (R)GDGGPPGATGFPGAAGR(T) + 2 ox & Collagen alpha-2(I) \\
\hline
\end{tabular}


Table 1. Cont.

\begin{tabular}{|c|c|c|c|}
\hline $\begin{array}{l}\text { Experimental } \\
\mathrm{m} / \mathrm{z}\end{array}$ & $\begin{array}{c}\text { Theoretical } \\
\mathrm{m} / \mathrm{z}\end{array}$ & Sequence & Identified Protein \\
\hline 1560.67 & 1560.73 & (K)STGISVPGPMGPSGPR(G) + 4 ox & Collagen alpha-1(I) \\
\hline \multirow{2}{*}{1562.80} & 1562.79 & (R)GDKGETGEQGDRGIK(G) + 1 ox & Collagen alpha-1(I) \\
\hline & 1562.83 & (K)GAAGLPGVAGAPGLPGPR(G) + 3 ox & Collagen alpha-2(I) \\
\hline \multirow{2}{*}{1586.74} & 1586.74 & (K)GNSGEPGAPGSKGDTGAK(G) & Collagen alpha-1(I) \\
\hline & 1586.70 & (R)GETGPAGPSGAPGPAGSR(G) + 4 ox & Collagen alpha-1(III) \\
\hline 1648.79 & 1648.78 & (K)AGEDGHPGKPGRPGER(G) + 2 ox & Collagen alpha-2(I) \\
\hline 1759.79 & 1759.82 & (K)GEPGPAGPQGAPGPAGEEGK(R) & Collagen alpha-1(II) \\
\hline 1832.80 & 1832.81 & (R)GPPGPMGPPGLAGPPGESGR(E) + 3 ox & Collagen alpha-1(I) \\
\hline \multirow{3}{*}{1922.94} & 1922.93 & (R)GERGPPGESGAAGPTGPIGSR(G) + 1 ox & Collagen alpha-2(I) \\
\hline & 1922.86 & (K)GDSGAPGERGPPGAGGPPGPR(G) + 5 ox & Collagen alpha-1(III) \\
\hline & 1975.99 & (K)SGDRGETGPAGPAGPIGPVGAR(G) & Collagen alpha-1(I) \\
\hline \multirow[t]{3}{*}{1975.90} & 1975.95 & (K)GEPGAVGQPGPPGPSGEEGKR(G) + 1 ox & Collagen alpha-2(I) \\
\hline & 1976.03 & (R)GPPGPQGARGFPGTPGLPGVK(G) + 2 ox & Collagen alpha-1(II) \\
\hline & 2131.03 & (R)GVQGPPGPAGPRGANGAPGNDGAK(G) + 2 ox & Collagen alpha-1(I) \\
\hline \multirow[t]{2}{*}{2131.01} & 2131.11 & (R)GLPGVAGSVGEPGPLGIAGPPGAR(G) + 3 ox & Collagen alpha-2(I) \\
\hline & 2130.95 & (R)GMPGPQGPRGDKGETGEAGER(G) + 3 ox & Collagen alpha-1(II) \\
\hline
\end{tabular}

\subsection{Angel's Blouse, Blue Layer (Sampled Point 3)}

Under the surface of the most recent painting, a blue layer was revealed (Figure 1, Sampled point 3). Minute quantities of the blue surface were removed and subjected to lipid extraction. The MALDI-MS spectrum in positive mode exhibited the presence of peaks at $m / z 732.8$ and 760.8 recognized as phosphatidylcholines from egg yolk [43-45] most likely employed as a paint binder. MALDI-MS/MS spectra of precursor ions at $\mathrm{m} / \mathrm{z}$ 732.8 and 760.8 as protonated adducts were respectively recognized as PC (32:1) and PC (34:1). Their fragmentation pattern appears typical for the class of PC which are easily identified through the diagnostic phosphocholine head-related ion at $m / z 184$ being the base peak when working in positive ionization mode. Concerning the precursor ion at $\mathrm{m} / \mathrm{z}$ 760.8 shown in Figure 6, the appearance of a very low abundance ion at $m / z 227.1$ could correspond to $[\mathrm{FA}(14: 1)+\mathrm{H}]^{+}$, thus suggesting the occurrence of a PC (14:1_20:0) considering that the sum composition should be PC(34:1). The presence of PC suggests the use of an egg-based binder for this painting layer since phosphatidylcholines typically compose the lipid fraction of egg yolk $[33,46,47]$. The use of this binder is corroborated by the ATR-FTIR spectrum acquired on the sample (Figure 7). In this case, the main signals at $3340,2916,2849,1734,1711,1643$, and $1541 \mathrm{~cm}^{-1}$ suggested the presence of a mixed binder of lipidic and proteinaceous components (such as egg yolk). In particular, the bands at 1734 and $1711 \mathrm{~cm}^{-1}$ are consistent with the presence of aged egg yolk, imputable to aldehydes and acids from triglycerides and/or imide bonds by oxidation of protein amidic bonds [48,49]. The spectral features at 1643 and $1541 \mathrm{~cm}^{-1}$ are compatible respectively with amide I and amide II stretching, though the higher intensity of the latter can be related to the contribution of calcium and lead carboxylates [49,50]. Calcium carboxylates could be responsible also for the shoulder at $1576 \mathrm{~cm}^{-1}$. The presence of basic lead carbonate can be inferred by a shoulder at $3535 \mathrm{~cm}^{-1}$ and the peaks at 1044 and $680 \mathrm{~cm}^{-1}$, whereas the signals at 1406 and $874 \mathrm{~cm}^{-1}$ are diagnostic for the use of $\mathrm{CaCO}_{3}$. Moreover, it is evident the characteristic band of CN stretching at $2087 \mathrm{~cm}^{-1}$, suggesting that Prussian blue is present as a pigment. Notably, the peak at about $1400 \mathrm{~cm}^{-1}$ of blue sampled areas was assigned to both basic lead carbonate and calcite $\left(\mathrm{CaCO}_{3}\right)$, even if its intensity is uneven in these two cases suggesting a stratigraphic differentiation. 


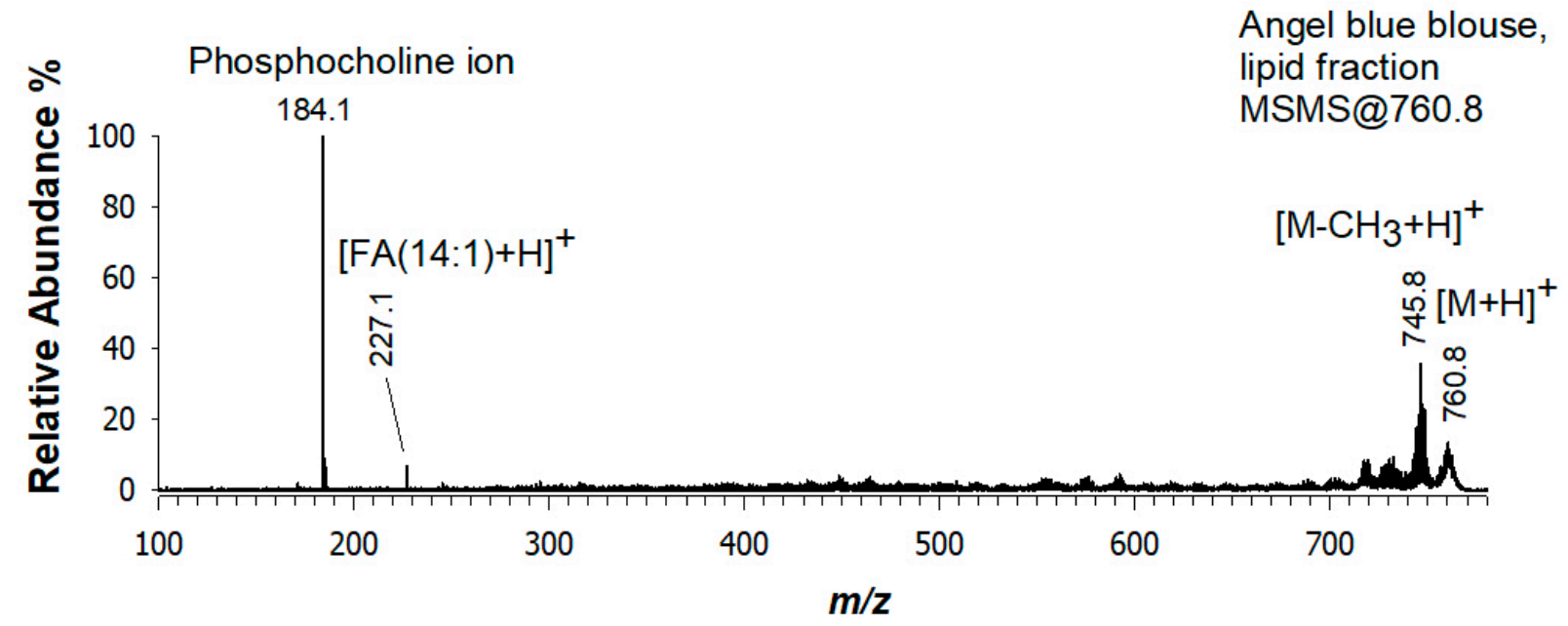

Figure 6. MALDI-MS/MS of a precursor ion as protonated adduct at $m / z 760.8$ assigned as a likely $[\mathrm{PC}(34: 1)+\mathrm{H}]^{+}$and retrieved in the angel's blouse onto the blue layer.

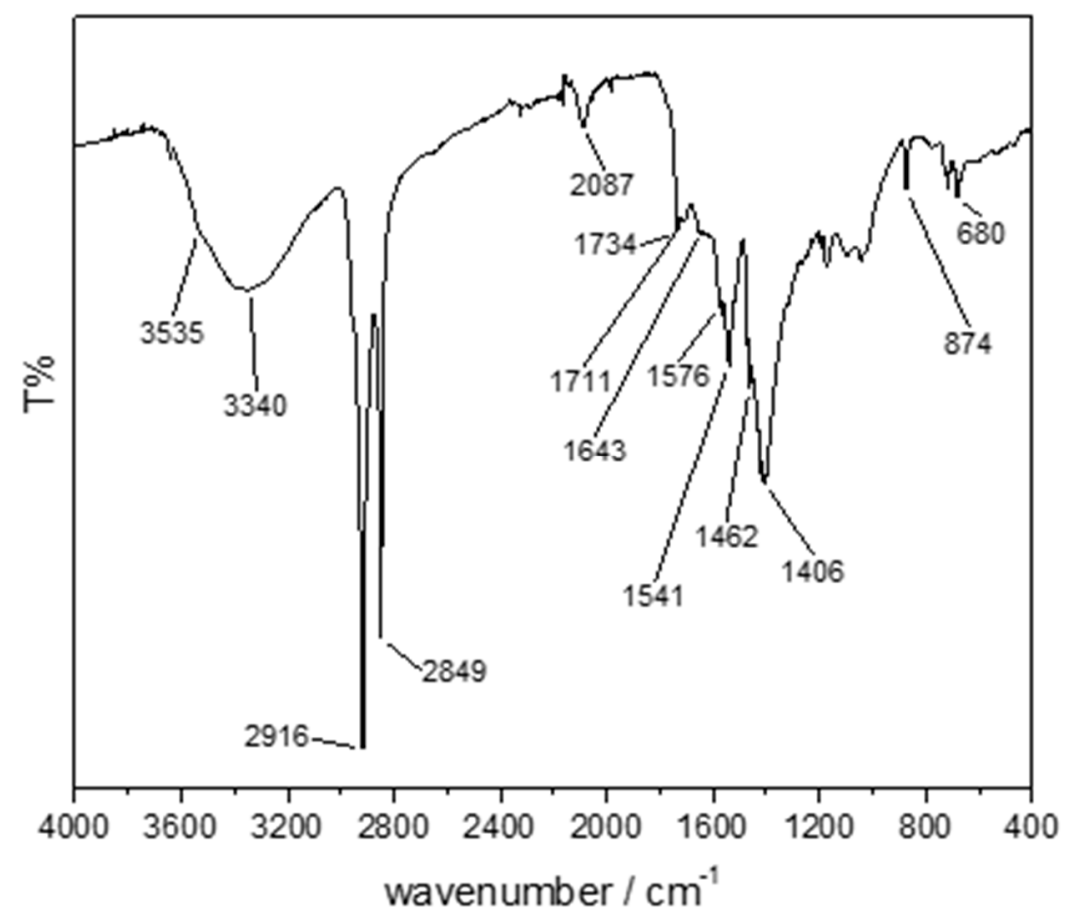

Figure 7. ATR-FTIR spectrum of blue layer (Blouse, samples point 3). The main peaks are signaled.

\subsection{Lying Lamb (Sampled Point 4)}

The micro-invasive procedure was carried out on a restricted zone of the lying lamb (see Figure 1, right-downside, Sampled Point 4). ATR-FTIR spectrum is explicative for the large heterogeneity of the sample (Figure S4). Inorganic fraction contributes to a larger extent to the spectrum's shape because the organic binder materials, usually represent a minor fraction of the overall painting composition [5]. In this case-by comparison with ATR-FTIR reference spectra of pigments as such and pigments with linseed oil freely available online [51-53] and other literature data [54,55] - a yellow (Italian gold) ochre (goethite, $\alpha$-FeOOH) can be presumably present, though the intensity of its associated peaks (Figure S4B) is quite low. These features are similar to those reported in [55]. In Sampled Point 4, the main signals (as labelled in Figure S4A) are ascribed to accessory minerals like $\mathrm{CaCO}_{3}$ (peaks at 1412, 873, and $712 \mathrm{~cm}^{-1}$ ) and gypsum (features at 3523, $3400,1620,1109,667$, and $600 \mathrm{~cm}^{-1}$ ), thus hindering the contribution of the pigment to the 
spectrum. In a similar way, only few signals associated to the binder (quite likely a drying oil) were identified at 2918, 2850, and $1738 \mathrm{~cm}^{-1}$.

Based on the MALDI-MS spectrum (Figure 8A), the lamb figure's lipid fraction is mainly composed of DAGs and TAGs as inferred from peak signals at $m / z 603.5$ and 881.7, $907.7,921.7,923.7,947.6[34,56]$, thus supporting the suggestion of a siccative oil-based painting mixture $[57,58]$. Contrary to the findings on the angel's blue wing, intact sodiated adducts of TAGs were detected and no by-products were visible. This outcome can be related to the additional presence of basic lead carbonate in the angel's wing being more assertive in oxidation/degradation reactions. The tandem MS spectrum (see Figure 8B) of the ion at $\mathrm{m} / \mathrm{z} 907.7$ allowed us to identify the sodium adduct of triolein, a triglyceride composed of three C18:1 fatty acyl chains as demonstrated by the single peak signal at $m / z 283.2$ recognized as protonated adduct of oleic acid, while the sodiated form of triolein losing neutral FA(18:1) could be due to the peak at $m / z 625.4$ as $[\mathrm{M}-\mathrm{FA}(18: 1)+\mathrm{Na}]^{+}$. Spacing $22 \mathrm{u}$, the signal at $m / z 603.5$ may be assigned as [M-FA(18:1)+H] $]^{+}$. Since the same fragmentation pattern was reported by Blanco-Zubiaguirre et al. [35], linseed oil can be plausibly suggested as a binder for this sample. To facilitate the results' interpretation, all pigments and binders identified in the present work are summarised in Table 2.

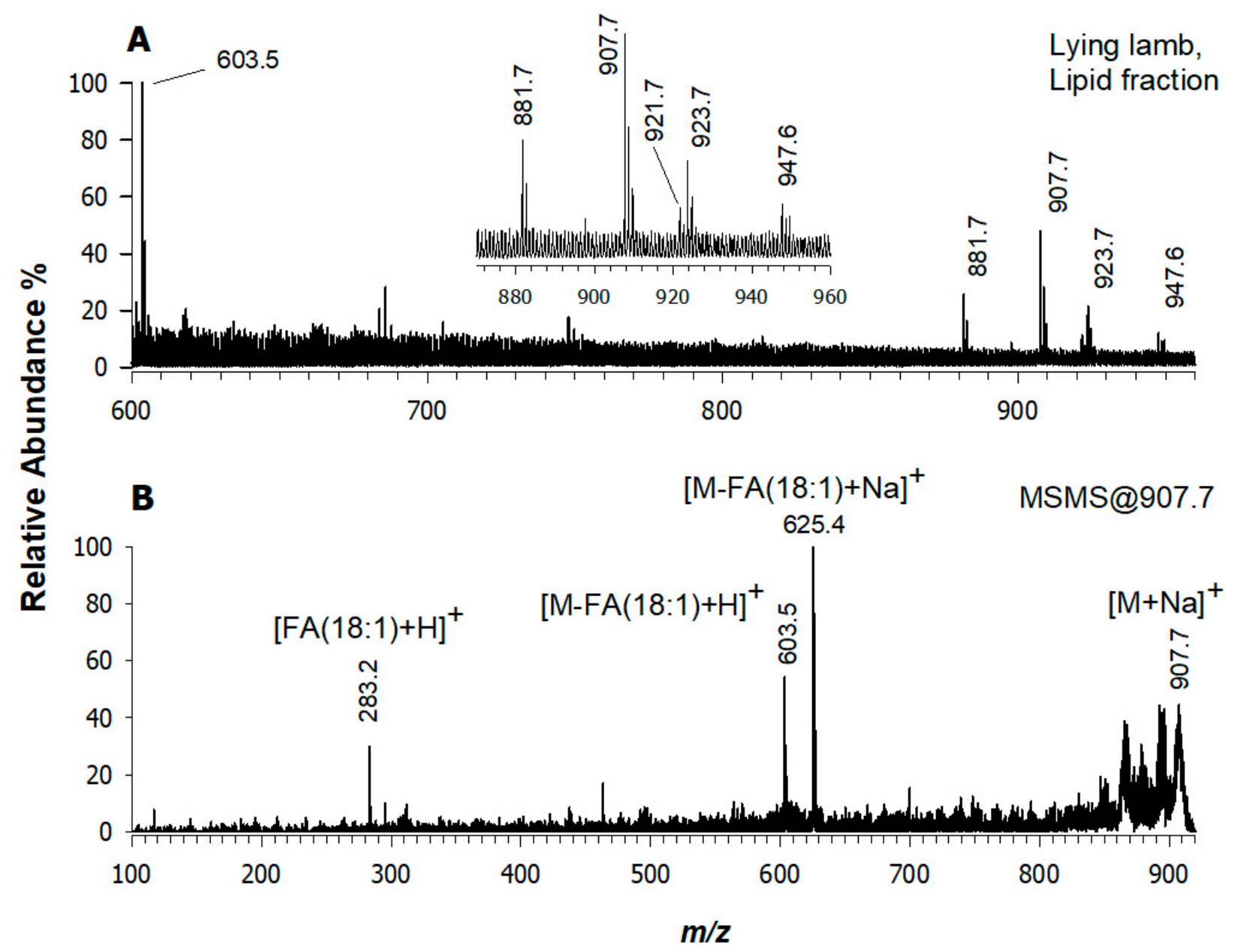

Figure 8. (A) MALDI-MS spectrum of the lipid fraction extracted from the sampling point on the lying lamb. (B) MALDIMS/MS spectrum of the precursor ion at $m / z 907.7$ was recognized as [TAG(54:3)+Na] $]^{+}$ 
Table 2. List of the pigment and binders identified in the sampled areas of the investigated sculptures.

\begin{tabular}{ccc}
\hline Sampled Zone & Components & Analytical Techniques \\
\hline & Prussian Blue $\left(\mathrm{Fe}^{\mathrm{III}}{ }_{4}\left[\mathrm{Fe}^{\mathrm{II}}(\mathrm{CN})_{6}\right]_{3}\right)$ & ATR-FTIR \\
Angel's wing, blue layer & Linseed oil & ATR-FTIR, MALDI-MS $(/ \mathrm{MS})$ \\
Angel's viola, brown layer & Egg white & MALDI-MS, RPLC-ESI-MS $/$ MS \\
Angel's blouse, blue layer & Animal collagen & MALDI-MS \\
& Prussian Blue $\left(\mathrm{Fe}_{4}^{\mathrm{III}}{ }_{4}\left[\mathrm{Fe}^{\mathrm{II}}(\mathrm{CN})_{6}\right]_{3}\right)$ & ATR-FTIR \\
Lying lamb & Egg yolk & ATR-FTIR, MALDI-MS $(/ \mathrm{MS})$ \\
& Yellow (Italian gold) Ochre $(\alpha-\mathrm{FeOOH})$ & ATR-FTIR \\
& Linseed oil & ATR-FTIR, MALDI-MS $(/ \mathrm{MS})$ \\
\hline
\end{tabular}

\section{Conclusions}

Given the physico-chemical complexity of polychromed statues reworked during time, the conservation and restoration of these unique objects exhibit considerable challenges. To address these issues a sound methodological approach is needed. To this aim, we presented a multi-technique investigation of organic and inorganic artistic materials employed in sculptural polychromies of different epochs belonging to the monumental Nativity Scene of Altamura's Cathedral (Bari, Italy). A micro- and a non-invasive approach were synergically combined to successfully achieve the extraction of both organic and inorganic portions. As summarized in Table 2, the bottom-up proteomic procedure allowed us to recognize residues of animal collagen and egg white in two different paint layers of the angel's sculpture; the multi-technique combination of MS and IR spectroscopy permitted to point out the occurrence of egg yolk's phospholipids and linseed oil's triglycerides in other sampling points both on the angel and the lying lamb figures. As for inorganic material, ATR-FTIR analysis revealed the identity of two pigments such as yellow (Italian gold) ochre and Prussian blue.

Supplementary Materials: The following are available online https://www.mdpi.com/article/ 10.3390/app11178017/s1. Figure S1: (A) eXtracted Ion Current chromatogram (XIC) of the ion at $m / z 854.7^{2+}$ retrieved in angel's blue wing. (B) RPLC-ESI-CID-MS/MS spectrum of the same ion corresponding to the sequence GSIGGGFSSGGFSGGSFSR (experimental monocharged $\mathrm{m} / \mathrm{z}$ 1707.7) and belonging to Keratin type I cytoskeletal 10 from Homo sapiens, $88.4 \%$ matched intensity. Figure S2: RPLC-ESI-CID-MS/MS spectrum of the ion at $m / z 771.6^{2+}$ retrieved in angel's blue wing, corresponding to the sequence IVN(deamidated)GEEAVPGSWPW (experimental monocharged $\mathrm{m} / \mathrm{z}$ 1541.6) and belonging to Chymotrypsinogen A from Bos taurus, $94.0 \%$ matched intensity. Figure S3: (A) eXtracted Ion Current chromatogram (XIC) of the ion at $\mathrm{m} / \mathrm{z} 930.6^{2+}$ (retention time $14.94 \mathrm{~min}$ ) retrieved in angel's blue wing. (B) RPLC-ESI-CID-MS/MS spectrum of the same ion corresponding to the sequence ELIN(deamidated)SWVESQTNGIIR (experimental monocharged $\mathrm{m} / \mathrm{z} 1859.8$ ) and belonging to Ovalbumin from Gallus gallus, 60.0\% matched intensity. Figure S4: (A) ATR-FTIR spectrum of sample taken from the lying lamb. Main signals are indicated. (B) Zoom of the IR region, diagnostic for signals of yellow ochre. Peaks compatible with the presence of yellow ochre are labelled.

Author Contributions: Conceptualization, C.D.C. and S.A.; methodology, C.D.C., E.C.L.R., R.A.P. and S.A.; formal analysis, E.C.L.R. and R.A.P.; investigation, C.D.C., E.C.L.R. and R.A.P.; data curation, C.D.C., E.C.L.R. and R.A.P.; writing—original draft preparation, E.C.L.R., C.D.C. and R.A.P.; writing - review and editing, T.R.I.C. and L.S.; funding acquisition, T.R.I.C. and L.S. All authors have read and agreed to the published version of the manuscript.

Funding: This research received funds from the University of Bari Aldo Moro "Fondi di Ateneo 17". The APC was funded by MDPI-Sciprofiles.

Institutional Review Board Statement: Not applicable.

Informed Consent Statement: Not applicable. 
Data Availability Statement: The authors confirm that most of the data supporting the findings of this study are available within the article and its Supplementary Materials. Raw data are available from the corresponding authors (C.D.C., L.S.) on request.

Acknowledgments: The authors thank Maria Piccarreta of the "Soprintendenza Archeologia, Belle Arti e Paesaggio per la città metropolitana di Bari" and the head of the territorial section of Altamura, Simona Cicala, for accessibility to the places and for historical-artistic information on the statues under study. This work was supported by the project PONa3_00395/1 “BIOSCIENZE \& SALUTE $(\mathrm{B} \& \mathrm{H})$ " of Italian Ministero per l'Istruzione, l'Università e la Ricerca (MIUR) for the use of facilities.

Conflicts of Interest: The authors declare no conflict of interest.

\section{References}

1. Campanella, L.; Casoli, A.; Colombini, M.P.; Bettolo, R.M.; Matteini, M.; Migneco, L.M.; Montenero, A.; Nodari, L.; Piccioli, C.; Zappalà, M.P.; et al. Chimica per L'arte; Zanichelli: Bologna, Italy, 2007; ISBN 9788808068538.

2. Previati, G. La Tecnica della Pittura; Sugarco: Milano, Italy, 1905.

3. Cennini, C. Il Libro Dell'arte, o Trattato della Pittura di Cennino Cennini; F. Le Monnier: Firenze, Italy; ISBN 9788828101482.

4. Vasari, G. Le Vite de' Piú Eccellenti Architetti, Pittori, et Scultori Italiani, da Cimabue Insino a' Tempi Nostri Nell'edizione per $i$ Tipi di Lorenzo Torrentino; Einaudi: Torino, Italy; ISBN 88-06-59659-4.

5. Piqué, F.; Verri, G. Organic Materials in Wall Paintings; Getty Conservation Institute: Los Angeles, CA, USA, 2015; ISBN 9781937433291.

6. Arie, W.; Hermens, E.; Peek, M. (Eds.) Historical Painting Techniques, Materials, and Studio Practice: Preprints of a Symposium Held at the University of Leiden, the Netherlands, 26-29 June, 1995; Getty Conservation Institute: Marina Del Rey, CA, USA, 1995; ISBN 0892363223. Available online: http://hdl.handle.net/10020/gci_pubs/historical_painting (accessed on 26 August 2021).

7. Kuckova, S.; Sandu, I.C.A.; Crhova, M.; Hynek, R.; Fogas, I.; Muralha, V.S.; Sandu, A.V. Complementary cross-section based protocol of investigation of polychrome samples of a 16th century Moravian Sculpture by optical, vibrational and mass spectrometric techniques. Microchem. J. 2013, 110, 538-544. [CrossRef]

8. Kuckova, S.; Sandu, I.C.A.; Crhova, M.; Hynek, R.; Fogas, I.; Schafer, S. Protein identification and localization using mass spectrometry and staining tests in cross-sections of polychrome samples. J. Cult. Herit. 2013, 14, 31-37. [CrossRef]

9. Franquelo, M.L.; Duran, A.; Castaing, J.; Arquillo, D.; Perez-Rodriguez, J.L. XRF, $\mu$-XRD and $\mu$-spectroscopic techniques for revealing the composition and structure of paint layers on polychrome sculptures after multiple restorations. Talanta 2012, 89, 462-469. [CrossRef]

10. Conti, C.; Colombo, C.; Realini, M.; Matousek, P. Subsurface analysis of painted sculptures and plasters using micrometre-scale spatially offset Raman spectroscopy (micro-SORS). J. Raman Spectrosc. 2015, 46, 476-482. [CrossRef]

11. Egel, E.; Simon, S. Investigation of the painting materials in Zhongshan Grottoes (Shaanxi, China). Herit. Sci. 2013, 1, 1-12. [CrossRef]

12. Križnar, A.; Muñoz, M.V.; de la Paz, F.; Respaldiza, M.A.; Vega, M. XRF analysis of two terracotta polychrome sculptures by pietro torrigiano. X-ray Spectrom. 2009, 38, 169-174. [CrossRef]

13. Pinna, D.; Conti, C.; Mazurek, J. Polychrome sculptures of medieval Italian monuments: Study of the binding media and pigments. Microchem. J. 2020, 158, 105100. [CrossRef]

14. Casoli, A.; Musini, P.C.; Palla, G. A study for the characterization of binding media from medieval polychrome sculptures by gas chromatography-mass spectrometry. Chromatographia 1996, 42, 421-430. [CrossRef]

15. Wang, X.; Zhen, G.; Hao, X.; Tong, T.; Ni, F.; Wang, Z.; Jia, J.; Li, L.; Tong, H. Spectroscopic investigation and comprehensive analysis of the polychrome clay sculpture of Hua Yan Temple of the Liao Dynasty. Spectrochim. Acta-Part A Mol. Biomol. Spectrosc. 2020, 240. [CrossRef]

16. Chen, E.; Zhang, B.; Zhao, F. Comprehensive analysis of polychrome grotto relics: A case study of the paint layers from Anyue, Sichuan, China. Anal. Lett. 2020, 53, 1455-1471. [CrossRef]

17. Gelao, C.; Tragni, B. Il Presepe Pugliese. arte e Folklore; Adda, 2000.

18. Fabris, D. Presepi scultorei con strumenti musicali del Cinquecento in Puglia. RIdIM/RCMI Newsl. 1991, 16, 8.

19. Saponaro, M. Il Presepe Cinquecentesco della Cattedrale di Altamura; Torre di Nebbia: Bari, Italy, 2007.

20. Calvano, C.D.; Rigante, E.; Picca, R.A.; Cataldi, T.R.I.; Sabbatini, L. An easily transferable protocol for in-situ quasi-non-invasive analysis of protein binders in works of art. Talanta 2020, 215, 120882. [CrossRef]

21. Calvano, C.D.; Rigante, E.C.L.; Cataldi, T.R.I.; Sabbatini, L. In situ hydrogel extraction with dual-enzyme digestion of proteinaceous binders: The key for reliable mass spectrometry investigations of artworks. Anal. Chem. 2020, 92, 10257-10261. [CrossRef]

22. Bligh, E.G. and Dyer, W.J. A rapid method of total lipid extraction and purification. Can. J. Biochem. Physiol. 1959, 37, 911-917. [CrossRef]

23. Van Der Werf, I.D.; Calvano, C.D.; Palmisano, F.; Sabbatini, L. A simple protocol for Matrix Assisted Laser Desorption Ionizationtime of flight-mass spectrometry (MALDI-TOF-MS) analysis of lipids and proteins in single microsamples of paintings. Anal. Chim. Acta 2012, 718, 1-10. [CrossRef] 
24. Domingues, J.A.L.; Bonelli, N.; Giorgi, R.; Fratini, E.; Gorel, F.; Baglioni, P. Innovative hydrogels based on semi-interpenetrating p(HEMA)/PVP networks for the cleaning of water-sensitive cultural heritage artifacts. Langmuir 2013, 29, 2746-2755. [CrossRef]

25. Micheli, L.; Mazzuca, C.; Missori, M.; Teodonio, L.; Mosca Conte, A.; Pulci, O.; Arcadipane, L.; Dominijanni, S.; Palleschi, A.; Palleschi, G.; et al. Interdisciplinary approach to develop a disposable real time monitoring tool for the cleaning of graphic artworks. Application on "le Nozze di Psiche". Microchem. J. 2018, 138, 369-378. [CrossRef]

26. Baglioni, P.; Baglioni, M.; Bonelli, N.; Chelazzi, D.; Giorgi, R. Smart Soft Nanomaterials for Cleaning; Elsevier Inc.: Amsterdam, The Netherlands, 2018; ISBN 9780128139110.

27. Mazzuca, C.; Poggi, G.; Bonelli, N.; Micheli, L.; Baglioni, P.; Palleschi, A. Innovative chemical gels meet enzymes: A smart combination for cleaning paper artworks. J. Colloid Interface Sci. 2017, 502, 153-164. [CrossRef]

28. Leo, G.; Bonaduce, I.; Andreotti, A.; Marino, G.; Pucci, P.; Colombini, M.P.; Birolo, L. Deamidation at asparagine and glutamine as a major modification upon deterioration/aging of proteinaceous binders in mural paintings. Anal. Chem. 2011, 83, 2056-2064. [CrossRef]

29. Doménech-Carbó, A.; Doménech-Carbó, M.T.; Osete-Cortina, L.; Donnici, M.; Guasch-Ferré, N.; Gasol-Fargas, R.M.; IglesiasCampos, M.Á. Electrochemical assessment of pigments-binding medium interactions in oil paint deterioration: A case study on indigo and Prussian blue. Herit. Sci. 2020, 8, 71. [CrossRef]

30. Fermo, P.; Mearini, A.; Bonomi, R.; Arrighetti, E.; Comite, V. An integrated analytical approach for the characterization of repainted wooden statues dated to the fifteenth century. Microchem. J. 2020, 157, 105072. [CrossRef]

31. Samain, L.; Silversmit, G.; Sanyova, J.; Vekemans, B.; Salomon, H.; Gilbert, B.; Grandjean, F.; Long, G.J.; Hermann, R.P.; Vincze, L.; et al. Fading of modern Prussian blue pigments in linseed oil medium. J. Anal. At. Spectrom. 2011, 26, 930-941. [CrossRef]

32. Mazzeo, R.; Prati, S.; Quaranta, M.; Joseph, E.; Kendix, E.; Galeotti, M. Attenuated total reflection micro FTIR characterisation of pigment-binder interaction in reconstructed paint films. Anal. Bioanal. Chem. 2008, 392, 65-76. [CrossRef]

33. Calvano, C.D.; Van Der Werf, I.D.; Palmisano, F.; Sabbatini, L. Fingerprinting of egg and oil binders in painted artworks by matrix-assisted laser desorption ionization time-of-flight mass spectrometry analysis of lipid oxidation by-products. Anal. Bioanal. Chem. 2011, 400, 2229-2240. [CrossRef]

34. Picariello, G.; Paduano, A.; Sacchi, R.; Addeo, F. MALDI-TOF mass spectrometry profiling of polar and nonpolar fractions in heated vegetable oils. J. Agric. Food Chem. 2009, 57, 5391-5400. [CrossRef] [PubMed]

35. Blanco-Zubiaguirre, L.; Ribechini, E.; Degano, I.; La Nasa, J.; Carrero, J.A.; Iñañez, J.; Olivares, M.; Castro, K. GC-MS and HPLC-ESI-QToF characterization of organic lipid residues from ceramic vessels used by Basque whalers from 16th to 17th centuries. Microchem. J. 2018, 137, 190-203. [CrossRef]

36. Herrera Cubero, L.; Potvin, M.A.; Melanson, J.E. Quantitative analysis of positional isomers of triacylglycerols via electrospray ionization tandem mass spectrometry of sodiated adducts. Rapid Commun. Mass Spectrom. 2010, 24, 2745-2752. [CrossRef]

37. Balgoma, D.; Guitton, Y.; Evans, J.J.; Le Bizec, B.; Dervilly-Pinel, G.; Meynier, A. Modeling the fragmentation patterns of triacylglycerides in mass spectrometry allows the quantification of the regioisomers with a minimal number of standards. Anal. Chim. Acta 2019, 1057, 60-69. [CrossRef]

38. Fremout, W.; Kuckova, S.; Crhova, M.; Sanyova, J.; Saverwyns, S.; Hynek, R.; Kodicek, M.; Vandenabeele, P.; Moens, L. Classification of protein binders in artist's paints by matrix-assisted laser desorption/ionisation time-of-flight mass spectrometry: An evaluation of principal component analysis (PCA) and soft independent modelling of class analogy (SIMCA). Rapid Commun. Mass Spectrom. 2011, 25, 1631-1640. [CrossRef]

39. Cicatiello, P.; Ntasi, G.; Rossi, M.; Marino, G.; Giardina, P.; Birolo, L. Minimally invasive and portable method for the identification of proteins in ancient paintings. Anal. Chem. 2018, 90, 10128-10133. [CrossRef]

40. Dallongeville, S.; Koperska, M.; Garnier, N.; Reille-Taillefert, G.; Rolando, C.; Tokarski, C. Identification of animal glue species in artworks using proteomics: Application to a 18th century gilt sample. Anal. Chem. 2011, 83, 9431-9437. [CrossRef]

41. van der Werf, I.D.; Calvano, C.D.; Germinario, G.; Cataldi, T.R.I.; Sabbatini, L. Chemical characterization of medieval illuminated parchment scrolls. Microchem. J. 2017, 134, 146-153. [CrossRef]

42. Hess, G.P.; McConn, J.; Ku, E.; McConkey, G. Studies of the activity of chymotrypsin. Philos. Trans. R. Soc. Lond. B Biol. Sci. 1970, 257, 89-104. [CrossRef]

43. Fuchs, B.; Schiller, J.; Süß, R.; Nimptsch, A.; Schürenberg, M.; Suckau, D. Capabilities and disadvantages of combined matrixassisted laser-desorption/ionization time-of-flight mass spectrometry (MALDI-TOF MS) and high-performance thin-layer chromatography (HPTLC): Analysis of egg yolk lipids. J. Planar Chromatogr. Mod. TLC 2009, 22, 35-42. [CrossRef]

44. Teuber, K.; Schiller, J.; Fuchs, B.; Karas, M.; Jaskolla, T.W. Significant sensitivity improvements by matrix optimization: A MALDI-TOF mass spectrometric study of lipids from hen egg yolk. Chem. Phys. Lipids 2010, 163, 552-560. [CrossRef] [PubMed]

45. Yuan, W.; Kang, S.-J.; Evans, J.E.; Cresswell, P. Natural Lipid Ligands Associated with Human CD1d Targeted to Different Subcellular Compartments. J. Immunol. 2009, 182, 4784-4791. [CrossRef]

46. Harvey, D.J. Matrix-assisted Laser Desorption/Ionization Mass Spectrometry of Phospholipids. J. Mass Spectrom. 1995, 30, 1333-1346. [CrossRef]

47. Calvano, C.D.; van der Werf, I.D.; Sabbatini, L.; Palmisano, F. On plate graphite supported sample processing for simultaneous lipid and protein identification by matrix assisted laser desorption ionization mass spectrometry. Talanta 2015, 137, 161-166. [CrossRef] 
48. Meilunas, R.J.; Bentsen, J.G.; Steinberg, A. Analysis of aged paint binders by ftir spectroscopy. Stud. Conserv. $1990,35,33-51$. [CrossRef]

49. Švarcová, S.; Kočí, E.; Plocek, J.; Zhankina, A.; Hradilová, J.; Bezdička, P. Saponification in egg yolk-based tempera paintings with lead-tin yellow type I. J. Cult. Herit. 2019, 38, 8-19. [CrossRef]

50. Sotiropoulou, S.; Sciutto, G.; Tenorio, A.L.; Mazurek, J.; Bonaduce, I.; Prati, S.; Mazzeo, R.; Schilling, M.; Colombini, M.P. Advanced analytical investigation on degradation markers in wall paintings. Microchem. J. 2018, 139, 278-294. [CrossRef]

51. Vahur, S.; Teearu, A.; Peets, P.; Joosu, L.; Leito, I. ATR-FT-IR spectral collection of conservation materials in the extended region of 4000-80 cm-1. Anal. Bioanal. Chem. 2016, 408, 3373-3379. [CrossRef] [PubMed]

52. Database of ATR-FT-IR Spectra of Various Materials. Available online: https://spectra.chem.ut.ee/paint/pigments/italian-goldochre-light/ (accessed on 26 July 2021).

53. Getty Conservation Institute. IMP00034, Ochre, Avana w/calcite, gypsum, Pigment Yellow 43 (PY43), CI77492” Ed. Beth, A. Price, Boris Pretzel and Susanne Quillen Lomax. Infrared and Raman Users Group Spectral Database. Infrared and Raman Users Group. 1992. Available online: http:/ / www.irug.org/ (accessed on 26 July 2021).

54. Rampazzi, L.; Corti, C. Are commercial pigments reliable references for the analysis of paintings? Int. J. Conserv. Sci. 2019, 10, 217-220.

55. Guglielmi, V.; Fermo, P.; Andreoli, M.; Comite, V. A multi-analytical survey for the identification of the red and yellow pigments of coloured sherds discovered in the Monte d'Oro area (Rome). In Proceedings of the 2020 IMEKO TC-4 International Conference on Metrology for Archaeology and Cultural Heritage, Trento, Italy, 22-24 October 2020; pp. 548-553. [CrossRef]

56. Saraiva, S.A.; Cabral, E.C.; Eberlin, M.N.; Catharino, R.R. Amazonian vegetable oils and fats: Fast typification and quality control via triacylglycerol (TAG) profiles from dry matrix-assisted laser desorption/lonization time-of-flight (MALDI-TOF) mass spectrometry fingerprinting. J. Agric. Food Chem. 2009, 57, 4030-4034. [CrossRef]

57. Vereshchagin, A.G.; Novitskaya, G.V. The composition of linseed oil. J. Am. Oil Chem. Soc. 1965, 42, 970-974. [CrossRef]

58. Tirat, S.; Degano, I.; Echard, J.P.; Lattuati-Derieux, A.; Lluveras-Tenorio, A.; Marie, A.; Serfaty, S.; Le Huerou, J.Y. Historical linseed oil/colophony varnishes formulations: Study of their molecular composition with micro-chemical chromatographic techniques. Microchem. J. 2016, 126, 200-213. [CrossRef] 